2. Faculty Development / Academy of medical educators. University of Colorado School of Medicine. 2019. [Електронний ресурс]- Режим доступу: http://www.ucdenver.edu/ACADEMICS/COLLEGES/MEDICALSCHOOL/EDUCATION/ACADEMY/ FACULTYDEVELOPMENT/Pages/default.aspx.

3. General Teaching / UCSF Continual Professional Learning. 2019. [Електронний ресурс]- Режим доступу: https://wiki.library.ucsf.edu/display/UCPLS/General+Teaching.

4. Mandell R. D. The Professor Game. What Really Goes on in the Multi Billion Dollar Education Industry / R. D. Mandell. - New York: Doubleday, 1977. - 275 p.

5. Residents and Fellows as Medical Educators Elective / Academy of medical educators, University of Colorado School of Medicine.- 2019. [Електронний ресурс]- Режим доступу: http://www.ucdenver.edu/ academics/colleges/medicalschool/education/academy/edelective/Pages/edelective.aspx.

\title{
REFERENCES
}

1. Advanced Teaching Skills / Harvard Medical School, 2019. URL: https://cmeregistration.hms.harvard.edu/events/advanced-teaching-skills/event-summary61975b435857420d9a815b86129ce1c9.aspx?RefID=cmecatalog.

2. Faculty Development / Academy of medical educators. University of Colorado School of Medicine, 2019. URL:

http://www.ucdenver.edu/ACADEMICS/COLLEGES/MEDICALSCHOOL/EDUCATION/ACADEMY/ FACULTYDEVELOPMENT/Pages/default.aspx.

3. General Teaching / UCSF Continual Professional Learning, 2019. URL: https://wiki.library.ucsf.edu/display/UCPLS/General+Teaching.

4. Mandell R. D. The Professor Game. What Really Goes on in the Multi Billion Dollar Education Industry. New York: Doubleday, 1977. 275 p.

5. Residents and Fellows as Medical Educators Elective / Academy of medical educators, University of Colorado School of Medicine, 2019.2 URL: http://www.ucdenver.edu/academics/colleges/medicalschool/education/academy/edelective/Pages/edelecti ve.aspx.

Стаття надійшла в редакиію 21.03.2019 p.

УДК 378.633.848:37.014.53

DOI 10.25128/2415-3605.19.1.6

NATALIIA ZHORNIAK

ORCID.ORG:0000-0001-9225-235X nataliazhorniak@gmail.com Candidate of Pedagogical Sciences, Associate Professor Lviv Polytechnic National University 12 Stepan Bandera Str., Lviv, Ukraine

\section{DEVELOPENT AND IMPLEMENTATION GUIDELINES FOR PROFESSIONAL TRAINING OF INDIGENOUS PEOPLES IN CANADA}

The article considers the key aspects of the development and implementation of vocational training programs for indigenous people in Canada, describes the specifics of indigenous professional activity, defines the concept of "indigenous peoples". Given the complex historical relationship between European emigrants and indigenous people, the issue of socialization of this stratum is given special attention. The main obstacles encountered in the path of indigenous people to obtaining vocational training, namely historical, social, geographic, demographic, cultural and individual, were studied. Cultural relevance is often used in schools only as an instrument of dominant ideologies, which promotes understanding of what it means to be a successful member of society. Of course, European standards became the criteria for success. And, despite all their importance, they, instead of having a positive impact on the development of education and community, were the usual mechanisms for the introduction of dominant concepts. Worldwide learning is basically the responsibility of the state. A universal goal of providing basic education is still at the stage of discussing how to effectively use local knowledge to support the priorities of the local community. The strategic directions of the development of the education of the indigenous inhabitants, in particular, the program of access, the provision of communication for the community, the control of the indigenous people over their own education, the 
cooperation between the indigenous communities and the leading educational institutions, and the support of the students that meets the needs of the indigenous people, are explored. Leaders and teachers of higher education institutions should ensure the development of teaching methods for indigenous peoples and the implementation of an educational structure that would meet the needs of the indigenous population. In addition, for the successful implementation of the educational process of the indigenous people, the Elders have been involved into it, which offered students and teachers a different way of acquiring knowledge and additional worldview. Particular attention is paid to the analysis of vocational training programs, their impact on the welfare of the community and the level of involvement of indigenous people.

Keywords: vocational training, indigenous people, community, the Elders, professional activity.

НАТАЛІЯ ЖОРНЯК

кандида педагогічних наук, доцент Національний університет «Львівська політехніка» вул. Степана Бандери 12, м. Львів, Україна

\section{ОСНОВНІ АСПЕКТИ РОЗРОБКИ ТА ВПРОВАДЖЕННЯ ПРОГРАМ ПРОФЕСІЙНОЇ ПІДГОТОВКИ ДЛЯ КОРІННОГО НАСЕЛЕННЯ КАНАДИ}

Розглянуто основні аспекти розробки та впровадження програм професійної підготовки для корінного населення Канади. Показано специфіку професійної діяльності корінного населення. Дано визначення поняття «корінні народи». Враховуючи складні історичні взаємовідносини між європейськими емігрантами та корінним населенням, питанню соціалізаџї цієї верстви приділяється особлива увага. Вивчено основні перешкоди, які трапляються на шляху корінного населення до здобуття професійної підготовки: історичні, сочіальні, географічні, демографічні, культурні та індивідуальні. Вказано, що культурна релевантність часто використовується в иколах лише як інструмент домінуючих ідеологій, який сприяє розумінню того, щуо означає бути успішним членом суспільства. Критеріями успішності ставали, звичайно ж, європейські мірила. Попри всю свою важливість, вони, замість того, щеоб позитивно впливати на розвиток освіти та спільноти, були звичайними механізмами запровадження домінуючих концепиій. У всьому світі навчання в основному є відповідальністю держави, а універсальні цілі забезпечення базової освіти все ще перебувають на етапі обговорення того, як ефективно використовувати місцеві знання задля підтримки пріоритетів місцевої спільноти. Досліджено стратегічні напрямки розвитку освіти корінних жителів, зокрема, програми доступу, забезпечення сполучення для спільноти, контроль корінних жителів за власною освітою, співпраия між корінними спільнотами та провідними навчальними закладами, підтримка студентів, щзо відповідає потребам корінних жителів. Зазначено, що керівники та викладачі вищих навчальних закладів повинні забезпечити розвиток методів навчання корінних жителів та впровадження структури освіти, яка відповідала би потребам корінного населення. Для успішного впровадження освітнього процесу корінних жителів до нього залучено старійшин, які запропонували студентам та викладачам інший спосіб отримання знань та інше світобачення. Проаналізовано програми професійної підготовки, їхній вплив на добробут спільноти і рівень залучення корінних жителів.

Ключові слова: професійна підготовка, корінне населення, спільнота, старійшини, професійна діяльність.

НАТАЛИЯ ЖОРНЯК

кандидат педагогических наук, доцент Национальный университет «Львовская политехника» ул. Степана Бандеры 12, г. Львов, Украина

\section{ОСНОВНЫЕ АСПЕКТЫ РАЗРАБОТКИ И ВНЕДРЕНИЯ ПРОГРАММ ПРОФЕССИОНАЛЬНОЙ ПОДГОТОВКИ ДЛЯ КОРЕННОГО НАСЕЛЕНИЯ КАНАДЫ}

Рассмотрены ключевые аспекты разработки и внедрения программ профессиональной подготовки для коренного населения Канады. Отмечена специфика профессиональной деятельности коренного населения. Дано определение понятия «коренные народы». Изучены основные препятствия, встречающиеся на пути к получению профессиональной подготовки коренными жителями страны и исследованы стратегические направления развития их образования. Особое внимание уделено анализу программ профессиональной подготовки, их влиянию на благосостояние сообщества и уровень привлечения коренных жителей Канады.

Наукові записки. Серія: педагогіка. - 2019. - № 1. 
Ключевье слова: профессиональная подготовка, коренное население, сообщество, старейшины, профессиональная деятельность.

With the advent of globalization, the desire to recognize the significance of the contribution of different cultures becomes immense. This is especially true of indigenous cultures. Indigenous peoples of Canada (according to the Canadian Multicultural Act and other legal instruments) are considered to be diverse tribes of Indians, Inuit and Metis, who reside in Canada. Now their number is almost 700 000 [9, p. 7]. Given the complex historical relationship between European emigrants and indigenous people, the issue of socialization of this stratum is given special attention. The Canadian Human Resources Development Council has launched a number of programs for the economic development of Indian communities. An important place among them is occupied by professional training programs.

Maintaining their socio-cultural peculiarities ethnic groups are constantly faced with the need to protect their rights as independent peoples. They seek recognition of their identity and lifestyle. Despite the fact that a number of such ethnic national communities has a fairly ancient origin, the world community focused on solving these problems no sooner than the $21^{\text {st }}$ century.

Over the last 25 years, the number of indigenous students enrolled into professional training has increased significantly, although their number, as compared to other students, is still negligible. The reason for this is poverty and unemployment among the indigenous people, their low self-esteem, the cultural mismatch of higher education institutions within their worldview, low level of pre-university training and biased attitude towards educational institutions due to assimilation policies.

The aim of this article is to analyze the positive international experience of developing and implementing programs for indigenous peoples in educational institutions of Canada.

For indigenous peoples comprehensive, pro-European education and its ideals of success historically meant a policy of destruction and assimilation - the destruction of indigenous identities, languages and cultural practices, assimilation in the Western and universally recognized as dominant societies. There are numerous examples of the impact of this process throughout the world on the culture, language, ecology and sovereignty of indigenous peoples. The colonial method of educating the local masses has never been aimed at ensuring equal treatment of indigenous people, but rather providing them with education in order to prepare them as good workers and to refrain them from rebellion against the authorities. As a result, the family and community of indigenous people as vital participants in the process of upbringing their own children have been underestimated or excluded from a sustainable educational process. At its best case, indigenous culture and languages were seen as tools for achieving the dominant educational goals, such as literacy and the elimination of poverty.

Cultural relevance is often used in schools only as a tool of dominant ideology that promotes understanding of what it means to be a successful member of society, and therefore learning has become a peculiar panacea for economic stability, environmental sustainability, development, and national security [10, p. 19]. The criteria for success were, of course, European standards. And in spite of all their importance, they were, instead of having a positive impact on the development of education and community, the usual mechanisms for the introduction of dominant concepts.

Among the main hindrances which occur in the process of educating indigenous peoples, it is worth highlighting the following: a) historical (as a result of assimilation policies that were carried out through educational institutions, pro-European education is perceived with hostility and distrust) $[9, \mathrm{p}$. 13]; b) social (discrimination, cultural insensitivity, lack of academic training, the need to abandon their culture, traditions and beliefs and comprehend a new form of reality) [6, p. 21]; c) geographic (places of post-school education are usually located far from the community's place of residence, and the government scholarship often covered the costs only partially) [3]; d) demographic (most of the native students begin to study at an older age, most students $(80 \%)$ are women who have families dependent on them financially, this fact is often not taken into account by program developers [12, $\mathrm{p}$. 7]; e) cultural (usually the structure of an educational institution has nothing to do with the values and beliefs of indigenous people); f) individual (weak motivation and low self-esteem) [15].

The problem of extinction of indigenous languages and cultures is that they can not be sustained or saved from the outside, that is, with the support of other countries. The source of traditional knowledge and doctrines dies along with the Elders, because oral methods of knowledge transmission prevail in this culture. And since several generations have been brought up on foreign beliefs and values, now, as the Canadian scientist Barbara Barnaby states, there is a generation that does not 
belong to any culture - the descendants of indigenous people have not become fully European, but have lost their own traditional vision of the world [4, p. 23].

Taking into account the above-mentioned challenges, provincial governments in Canada are developing and implementing special measures and guidelines to improve the current situation. For example, the British Columbia Government has developed the following strategic directions for the development of indigenous education: a) access programs - special conditions and support for admission to higher education, training and transfer for the indigenous people; b) provision of commutation for the community - most of the indigenous people live in remote areas, the organization of transporting to educational institutions has significantly improved the submission of Aboriginal people to educational programs; c) control of indigenous people over their own education - that helps to overcome the aboriginal marginalization, increase their self-affirmation, as well as involves indigenous peoples in the development and implementation of a curriculum for the indigenous population; d) cooperation between indigenous communities and leading educational institutions - it helps to develop relevant and accessible curricula and plans and restore the Aboriginal trust in the European type of higher education; e) support for indigenous students, "A Home Away From Home" is a special campus program for acclimatization and the habituation of Indians to live in a new urban community. [7, p. 28]

For professional training to obtain its national characterisics, Rainer C. Rossing, a Canadian researcher on vocational education, outlined three of its main tasks: to meet the needs of a specific community of professionals, to increase choice and accessibility for each potential student, and to contribute to improving the quality of all types of vocational training [11, p. 98].

Life-long learning becomes the guiding principle of the learning continuum. Through lifelong learning (continuous education) we understand the entire cycle of learning - from learning in the childhood, formal education of all levels to self-study throughout adult life, including distant education, regardless of whether or not it is granted with certificates, diplomas, etc.

In Canadian vocational training special attention is paid to pre-vocational (undergraduate) training. For example, in September 1998 Alberta Training for Excellence Corporation (ATEC) introduced a new national tourism training program called "You Decide How Far To Go". Professionals of the tourism industry volunteered to present their career opportunities in the tourism industry. Presentations were held both for future university and college applicants (in senior grades) and those who wanted to gain additional knowledge for career development in this field [14]. Professional training is carried out by the method of integration of professional disciplines into high school programs [15].

Within the course "Fundamentals of Tourism", students cover the topic "Tourism of British Columbia" during which they are to study the history and culture of the indigenous people, the cultural diversity of the province, be able to analyze the factors that influence the development of local tourism in terms of culture and traditions of indigenous peoples [13, p. 131]. A separate topic under studying is "Positive Attitude To Your Career". Particular attention is paid to the development of a sense of responsibility, the development of behavioral models in the event of unforeseen situations, the ability to adapt to the workplace, taking into account its diversivity, understanding the need for further career growth [13, p. 134]. Career guidance counselors at higher education institutions carry out equally important professional superision. It is the career counselors who help with the choice of selective, highly specialized courses at the final stage of study.

It is worth noting that indigenous peoples' involvement in educational process takes place both explicitly and implicitly. On the one hand, higher education and schools create special conditions for admission and training for Aboriginal people, on the other - with the help of individual courses or modules, they acquaint others with the culture, customs and life of these peoples. Most leading Canadian universities, as well as colleges, have Aboriginal Studies Departments and the sites of almost all of them contain Aboriginal Access Programs. This is precisely the aspect of activity that is controlled and developed by the Government of Canada, not the provinces. Moreover, in many higher educational institutions where tourism industry specialists are trained, they offer diploma programs in the field of tourism activities of indigenous people.

For example, at the Malaspina University College, they offer the "Indigenous Tourism" course, which studies the fundamentals of indigenous tourism with an emphasis on the peculiarities of the British Columbia communities. The suggested themes of the course are indigenous tourism

Наукові записки. Серія: педагогіка. - 2019. - № 1. 
development, indigenous tourism organization, ongoing provision of indigenous tourist services, indigenous peoples' logos on tourist products, ties with the tourism industry, ecotourism and indigenous population trends [2, p. 7].

Another proposed course is "Community Development for Leisure and Tourism". This course examines the role of leisure for community planning and development, the potential role of recreation in promoting dynamic community prosperity. The themes of the course cover social and political processes through which groups and individuals work to build links and mobilize resources to meet public, recreational and tourist needs. Students acquire the skills and knowledge necessary for practical tourism activities in the public or private sector [2, p. 10].

The Thompson Rivers University launched the course "Community and Culture Issues in Tourism". It gives an insight into what culture is and how it interacts with tourism. Attention is drawn to intercultural issues and the difficulties that arise when meeting the needs of the local community and tourists. The course examines a wide range of diverse cultural issues, market approaches, methods of development and management of cultural tourism [2, p. 12].

Generally speaking, on successful completion of suchlike courses students are expected to be able to define the concept of indigenous and cultural tourism and tourism activities in the Canadian context, explore long-term areas for Aboriginal tourism development, for example, spiritual transformation, eco-tourism, as well as the main types of gambling business, describe several successful tourist attractions or attractions that belong to indigenous peoples and which are part of indigenous tourism, explain the process of sharing traditional knowledge, develop a scheme for the step-by-step development of the indigenous tourism product, explain how to work with the Elders and the community in introducing indigenous tourism, find examples of really existing indigenous activities that illustrate significant progress in product development, evaluate the quality of the new indigenous tourism product in accordance with its authenticity, stability and compliance with potential markets [1, p. 6].

While studying such courses, students learn about the unique features of indigenous tourism, in particular, participating in discussions on cultural authenticity and protocol. They develop projects of the main attractions of indigenous tourism, give their own assessment of the new indigenous tourist products, and then create their own concept of business in the field of indigenous tourism. Community consulting related to their business development is carried out within the concept of development.

The Human Resources Development Council has developed a number of general guidelines for the successful implementation of vocational training programs for indigenous people and for those who want to work with them, namely, the involvement of Indians in teaching activities, taking into account cultural diversity, maximizing the involvement of the community in the practical aspects of vocational training, checking the means of testing for cultural conformity, and developing a curriculum with global perspectives.

In their research Anna Augusto Rodrigues and Phil Raby analyze one more successful attempt to indigenize the studying at Durham community college in Ontario. In their two-year program students learn how to create content for multiple platforms, which include radio, television and web. This was part of a broader endeavor to implement some of the recommendations stemming out of the Truth and Reconciliation Commission of Canada. The work completed included a student focus group, educational workshops for non-Indigenous faculty members and the creation of internal media assets featuring Indigenous themes. It also resulted in the development of a new compulsory course on Indigenous perspectives in contemporary media that was added to the college's Broadcasting program. To make sure the program was in the least possible ways impacted by their inherent colonial viewpoints the researchers made extensive efforts concerning their self-education. They read books on the effect of colonialism in Canada, fiction and poetry written by Indigenous authors and watched documentaries on past and current issues affecting Indigenous peoples, attended workshops at the First Peoples Indigenous Centre and completed online courses focused on learning Indigenous perspectives, culture and histories within a Canadian context.[10, p. 21]

Information and communication technologies became part and parcel in almost any activity for a great number of people in the world today. Subsequently, the use of technology as a teaching tool promotes student participation and interaction. Online interaction can set up and create educational spaces that empower students to communicate in different, creative ways, and to explore and learn about other cultures. With the help of computer technology learning has acquired a new meaning, it 
promotes higher achievement as well as personal and social development. Owing to technological component the tasks are more student-centered, they foster creativity and allow students to take charge of their own learning while working both individually and collaboratively, gathering information, examining issues and resolving problems. Besides, computer-mediated communication provides a framework for teaching and learning from a distance which is of vital importance for some indigenous communities that occupy remote rural areas.

One of Canada's provinces, Nova Scotia, seeks to make education and training more accessible to communities through the use of new technologies and the improvement of the quality and efficiency of the education system through its restructuring. The development of a learning culture will enable all residents of Nova Scotia to participate in changing the global economy [8, p. 34].

Northwest Territories are also focusing their efforts on the use of information networks to support personal development and learning, as well as the implementation of innovative approaches to program launching. Within these guidelines, the Department of Education develops computer operating systems for aboriginal languages and helps people in all communities of Northwest Territories access the information networks [5, p. 6].

In addition to the introduction of the vast variety of courses, on the basis of the integration principle, the inclusion of additional content elements in educational curricula and educational programs of other specialized disciplines is carried out. Moreover, they implement innovative forms and methods of creative, research and simulative approach to the students' activity in studying these disciplines These activities help students acquire the necessary level of knowledge about diverse environments, the existence of a diversity of cultures, value attitudes towards the characteristics of existing diverse cultures and their representatives, as well as the skills and abilities of interaction in such environment. They also affect professional skills, the ability to focus on a diverse workplace, and the skills of working with clients.

The principles of program development are presented in the most consumer attractive way, they have more advertising elements. This is due to the fact that vocational education in Canada is marketoriented. An important element of each professional program is the feedback from the former students about continuing education and career development. They are usually placed in promotional brochures or on educational institutions' websites.

Over the past decades, Indian education has undergone radical changes and has begun to respond to the philosophy and needs of the Indian people. What is happening in education today determines the vision of the future of indigenous peoples. The recent recognition by the Government of the rights of indigenous peoples has substantially improved the situation with their socialization. As we see in the examples analyzed, when developing and implementing vocational training programs, their planners declined the practice of cultivation and acknowledged that the influence of European colonizers was not always positive. The mistakes of the past have caused irreparable losses to the indigenous population. Recognizing it is already an opportunity for growth, as it contributes to positive changes and the search for solutions to the difficult situations.

\section{REFERENCES}

1. Aboriginal Tourism Management Diploma Program: Core Curriculum Handbook. - Province of British Columbia: Ministry of Advanced Education, 2006. - 25 p.

2. Bachelor of Tourism Management Degree Program: Resource Handbook. - BC Provincial: Ministry of Advanced Education, 2007. - 27 p.

3. Budhwar P. Comparative Analysis of Cultural Value Orientations of Indians and Migrant Indians in the USA / Pawan S. Budhwar, Habte Woldu, Emmanuel Ogbonna // International Journal of Cross Cultural Management. - NY: Sage Publications, 2008. - Vol. 8(1). - P. 79-105. [Електронний ресурс] - Режим доступу: http://www.sagepub.co.uk/JournalsPermis sions.nav.

4. Burnaby B. Aboriginal Language Maintenance, Development and Enhancement: A Review of Literature / Barbara Burnaby // Stabilizing Indigenous Languages / ed. by Gina Cantoni. - Arizona: Northern Arizona University, 2007. - P. 21-31.

5. Continuing Education: Paper for Discussion at the Third National Forum on Education (May, 28-30, St. John's, Newfoundland). - Toronto: Council of Ministers of Education, 1998 - 15 p.

6. Grant, A. The Challenge for Universities / Agnes Grant // First Nations Education in Canada: The Circle Unfolds / ed. by Marie Battiste, Jean Barman. - Vancouver: UBC Press, 1999. - 211 p.

7. McKenna S. Aboriginal Participation in Tourism Planning in British Columbia / Sarah McKenna. Ontario: University of Waterloo, 2010. - 132 p. 
8. Mock K. Race Relations Training in Canada: Towards the Development of Professional Standards / Karen R. Mock, April Laufer. - Toronto: The Canadian Race Relations Foundation, 2001. -77 p.

9. Redefining How Success is Measured in First Nations, Inuit and Metis Learning: Report on Learning in Canada. - Ottawa: Canadian Council on Learning, 2007. - 47 p.

10. Rodrigues A. A., Raby Ph. Lessons Learned from Indigenizing a Media Program at an Ontario Community College / Anna Augusto Rodrigues, Phil Raby // College Quarterly - Ontario: SENECA PRESS, 2018. - Vol. 21, Issue 3 Seneca press Ontario - P. 17-32.

11. Rossing R. Parameters for an Effective Entrepreneurial, Regional, Hotel/Restaurant Management Training Programe in Manitoba / Rainer C. Rossing. - Winnipeg: University of Manitoba, 1997. - 222 p.

12. Smith P. Demographic Effects on the Use of Vertical Sources of Guidance by Managers in Widely Differing Cultural Contexts / Peter B. Smith, Mark F. Peterson // International Journal of Cross Cultural Management. - NY: Sage Publications, 2005. - Vol. 5 (1). - P. 5-26. [Електронний ресурс] - Режим доступу: http://citeseerx.ist.psu.edu/viewdoc/download?doi=10.1.1.827.8136\&rep=rep1\&type=pdf.

13. Stepping Stones: Tourism 11 and 12 Instructor Guide / ed. by Lori Fogarty. - BC: Tourism British Columbia, 2004. - $166 \mathrm{p}$

14. Tourism Studies: Guide to Standards and Implementation Career \& Technology Studies. - Edmonton: Curriculum Standards Branch, 1997. -388 p.

15. Transforming Communities through Tourism: A Handbook for Community Tourism Champions. - BC: The Tourism and Hospitality Educational Network, 2004. - 91 р. [Електронний ресурс] - Режим доступу: http://www.bctorc.ca.

Стаття надійшла в редакиію 27.03.2019 p.

УДК 378(430)

DOI 10.25128/2415-3605.19.1.7

НАТАЛІЯ РОКІЦЬКА

ID ORCID https://orcid.org/0000-0001-9192-6113 ndaniw@ukr.net

кандидат педагогічних наук, доцент

Тернопільський національний педагогічний університет імені Володимира Гнатюка вул. Максима Кривоноса 2, м. Тернопіль, Україна

\section{ПРОФЕСІЙНА ПІДГОТОВКА «ЕВРОВЧИТЕЛЯ» ХХІ СТОЛІТТЯ: ПРІОРИТЕТИ НІМЕЧЧИНИ}

Проаналізовано модель професійної підготовки вчителів іноземних мов новітнього взірия у вишах Німеччини на сучасному етапі в контексті загальноєвропейської консолідачії. Відзначено, що однією $з$ численних ініціатив Ради Свропи (РE) та Європейського Союзу (ЄС) є розробка нових підходів мовної освіти, навчання іноземних мов на всіх освітніх рівнях. Доведено, щзо педагогічна освіта та професійна іншомовна підготовка у Німеччині - це складний, багатокомпонентний прочес, спрямований на результат, а саме: висока професійна кваліфікація молодих учителів і високий статус професї̈ вчителя у суспільстві. Виокремлено ключові компоненти ефективності иієї підготовки, щяо забезпечується иілеспрямованою державною підтримкою, послідовною освітньою політикою, продуманими реформами, які реалізуються у німецькій вищій школі після приєднання крайни до Болонського прочесу. Охарактеризовано зроблені у цьому напрямку кроки, узагальнено організаційні та змістові перебудови, проаналізовано пріоритети діяльності. У контексті інтеграчії украӥнської освіти з європейським освітнім простором акцентовано увагу на необхідності модернізації системи педагогічної освіти загалом, іншомовної зокрема, та професійної підготовки вчителя іноземної мови.

Ключові слова: $Є C$, загальноєвропейська консолідація, підготовка вчителів іноземних мов у Німеччині, освітня політика, реформування, інтеграція України.

НАТАЛИЯ РОКИЦКАЯ

кандидат педагогических наук, доцент Тернопольский национальный университет имени Владимира Гнатюка 